\title{
Educação jesuítica na América Portuguesa: a dispensa das leis positivas e a racionalidade mercantil
}

Célio Juvenal Costa Anderson dos Santos de Oliveira? Universidade Estadual de Maringá

\section{Resumo}

objetivo deste artigo é determinar a plausibilidade de nossa tese de que as solicitações da dispensa das leis positivas, presentes nas cartas jesuíticas enviadas da América Portuguesa no século XVI, demonstram que a atuação dos missionários, no Brasil quinhentista, além de seus fins religiosos, foi marcada, também, pela racionalidade mercantil. Defende-se, assim, que os jesuítas agiam antenados às contingências daquela realidade europeia, lusa e brasílica. Ao espírito reformista somava-se a mentalidade mercantil, que dava à missão a feição de empreendimento religioso, na qual a lógica de se ter lucros espirituais direcionou a práxis daqueles mercadores de almas.

Palavras-chave: Companhia de Jesus. Racionalidade mercantil. América Portuguesa.

\section{Education jesuitin Portuguese America: the positive laws cancellation and the market rationality}

\section{Abstract}

The objective of this paper is to determine the plausibility of our thesis that the requests of positive laws cancellation, present in the Jesuit letters of Portuguese America in the sixteenth century, show that the action of missionaries in Brazil in the 16th century, in addition to its religious purposes, have been marked also by market rationality. We argue that the Jesuits acted tuned to contingencies that European, Portuguese and Brazilian reality. The reformist spirit amounted to merchant mentality, and gave the mission the garb of religious enterprise. Thus, the logic to have spiritual profite directed the praxis of those souls merchants.

Keywords: Society of Jesus. Market rationality. Portuguese America. 


\section{La educación jesuita en el América Portuguesa: la exención de las leyes positivas y la racionalidad del mercado}

\section{Resumen}

El propósito de este artículo es determinar la verosimilitud de nuestra tesis de que las peticiones de la exención de las leyes positivas, presente en las cartas de los jesuitas de la América portuguesa en el siglo XVI, muestran que la acción de los misioneros en Brasil del siglo XVI, además de sus fines religiosos, estuvo marcada también por la racionalidad del mercado. Argumentamos que los jesuitas actuaron en sintonía con las contingencias que la realidad europea, portuguesa y Brasilica. El espíritu reformista ascendió a la mentalidad de comerciante, y le dio la misión de la vestimenta de la empresa religiosa. Por lo tanto, la lógica de obtener lucros espirituales dirigió la praxis de eses comerciantes de las almas.

Palabras-clave: Compañía de Jesús. Racionalidad del mercado. América Portuguesa.

\section{Introdução}

A instituição de leis a serem seguidas por um determinado povo, por uma determinada sociedade, é algo inerente à sociabilidade humana. A criação de regras sociais que limitam e direcionam a ação do indivíduo é resultado da necessidade da convivência coletiva e do respeito a certos valores, instituídos por grupos ou pessoas.

As primeiras leis, quando da inexistência da escrita e antes de uma racionalidade mais contábil, se estabeleciam de forma consuetudinária, se tornando práticas a partir da tradição dos costumes. A lei grega da época heroica de se tratar bem as visitas, por exemplo, garantia, ou procurava garantir o deslocamento de pessoas, das informações e, especialmente, das atividades diplomáticas, no caso das cortes.

As leis consuetudinárias eram uma prática social durante boa parte da chamada ldade Média. Especialmente nos seus períodos iniciais, de formação dos reinos bárbaros e da feudalização da Europa, as regras sociais se impunham normalmente a partir dos mandatários, que se julgavam com certos privilégios inerentes à sua função social, os quais criavam normas que, com o tempo, passavam a ter o caráter de lei, ou seja, de subordinar e obrigar as 
ações dos indivíduos. $\bigcirc$ direito do senhor feudal à primeira noite da noiva serva vigorou em vários locais como um instrumento de poder do senhorio que tinha o direito de vida e morte de seus campesinos.

Com a volta do comércio a partir do século XI e suas derivações históricas, como o ressurgimento das cidades, da vida urbana, da escola, do refortalecimento da lgreja Cristã e processo de centralização do poder político, mudanças ocorreram no estabelecimento das leis, as quais, paulatinamente, passaram de consuetudinárias para positivas.

As leis positivas, ou o direito positivo, é característico de uma sociedade que tem, no estabelecimento escrito das regras, a regulação da vida em sociedade, regras que se tornam claras para todos na sociedade, os quais, a partir de então, não podem alegar o desconhecimento das leis para justificar práticas tidas como criminosas. No mundo ocidental moderno, a sociedade da Baixa ldade Média inaugurou o direito positivo inspirado, em grande medida, pela compreensão cristã no estabelecimento do que se tornou lícito e ilícito no agir das pessoas.

Direito Canônico inspirou, em grande medida, o Direito Civil, a 220 ponto de, por exemplo, nas Ordenações Manuelinas, conjunto de leis promulgadas em Portugal em 1603, já à época da União lbérica, ter como um dos seus primeiros graves crimes a heresia. No período da Baixa ldade Média e, em grande parte, na própria Modernidade, o conjunto das leis positivas civis eram provenientes da visão de mundo cristã, visão essa que era pesquisada, publicada e normatizada pelos clérigos. Legislação e religião se misturavam, conforme afirma Paiva, refletindo sobre a religiosidade como marca da cultura brasileira nos séculos XVI e XVII,

A secularização procede por via jurídica e não por oposição à religião. $\bigcirc$ entendimento que a sociedade corpo social tem de si mesma se desdobra, harmoniosamente, em afirmações de princípios que, incorporados à prática social, refazem o argumento: mantendo a consideração à religião, explicitando-se mesmo em termos teológicos, levam a uma mudança na compreensão da realidade. A própria Teologia se racionaliza, - São Tomás se faz paradigmático - embasando religiosamente o novo entendimento. Tem-se uma caminhada: do religioso para o jurídico, da Teologia para o Direito, preservando-se, contudo, as mesmas imagens poder divino, sacerdócio, liturgia, sacralidade etc (PAIVA 2012, p. 36, grifos no original). 
No que dizia respeito à atuação educacional e catequética que os padres jesuítas tiveram na América Portuguesa, sobretudo, no século XVI, o direito positivo impunha certas normas que deveriam ser seguidas especialmente no que se referia à conversão dos chamados gentios, os índios. As normas que deveriam se estender aos gentios eram, de certo modo, as mesmas que se esperava de qualquer súdito lusitano e de qualquer cristão, onde ele estivesse. Qualquer súdito e qualquer cristão lo que, aliás, até os seiscentos eram sinônimos em Portugal) deveriam observar regras no se vestir, no se relacionar, no se casar etc., para que a sociedade tivesse uma determinada direção e ordem.

No entanto, no quinhentos, especialmente nas terras de conquista e expansão portuguesas, um outro elemento, aliás, impulsionador da existência do direito positivo, é tão determinante como a religião: se trata do mercantil. A racionalidade mercantil que esteve na base das mudanças sociais da Baixa Idade Média se estendeu por toda a Modernidade, adquirindo uma espécie de "roupagem" religiosa e, portanto, esteve presente nas ações dos padres missionários na América Portuguesa do século XVI.

objetivo deste artigo é determinar a plausibilidade de nossa tese de que as solicitações da dispensa das leis positivas, presentes nas cartas jesuíticas enviadas da América Portuguesa no século XVI, fazem parte da processo educacional indígena e evidenciam que a ałuação dos missionários, no Brasil quinhentista, além de seus fins evidentemente religiosos, foi marcada também pela mentalidade mercantil que predominava tanto na Europa quanto no Império Lusitano. Essas leis não permitiam o casamento entre parentes, e os índios, em sua maioria, eram casados com os próprios familiares. Uma vez que os missionários não poderiam realizar os casamentos desses gentisinfratores, ficavam impedidos de batizá-los. Assim, o bom andamento das missões expresso pela quantificação dos sacramentos - estaria comprometido. Com efeito, foram necessários vários pedidos que culminaram na dispensa dessas leis para alguns casos específicos dos gentis.

A nova Ordem religiosa, criada por Inácio de Loyola e seis companheiros, emergiu da realidade quinhentista europeia, um período de avultamento comercial, de reformas religiosas e de novos emparelhamentos em todos os âmbitos da existência humana. A despeito de que o objetivo primário dos irmanados fosse a conquista de Jerusalém por meio da pregação da santa fé católica, em vista dos impedimentos à perseguição desse ideal, colocaram-se 
à disposição do Vigário de Cristo. Diante disso, em 1540, mediado por D. Diogo de Gouveia e D. Pedro Mascarenhas, embaixadores portugueses em Paris e Roma, D. João III (1521-1557), Rei de Portugal, solicitou ao Papa Paulo III (1534-1549) alguns de seus membros para exercer o Padroado Luso na Índia. Em atenção ao pedido, Simão Rodrigues e Francisco Xavier foram enviados à Coroa Portuguesa e, diante da empatia gerada entre a corte e os jesuítas, o primeiro teve de permanecer no reino e somente o segundo foi enviado às missões.

Com o tempo, os laços entre os missionários e os portugueses se estreitaram - uma vez que Portugal ansiava por uma reforma religiosa e a Companhia exalava um espírito reformista -, e os membros da nova Ordem desempenharam várias funções no território lusitano. Não obstante, o principal objetivo dos jesuítas era a missão, ou seja, exercer o Padroado Português em seus domínios. Assim, em 1549, seis jesuítas, chefiados pelo P. Manoel da Nóbrega, foram enviados por D. João III, juntamente com Tomé de Souza, primeiro Governador do Brasil (1549-1553), à América Portuguesa, onde permaneceram por 210 anos, até sua expulsão em 1759, desenvolvendo atividades missionárias, educacionais, catequéticas e evangelizadoras, dentre 222 outras.

Defende-se que a Companhia de Jesus, mais do que ser uma Ordem criada em meio aos e fomentadora dos ideais dos movimentos de reforma interna da lgreja Romana, também estava antenada e agia consoante a mentalidade comercial vigente naqueles tempos. Nessa análise, ela sempre foi considerada uma instituição humana, criada, organizada e constantemente repensada por homens do século XVI. Além de seus princípios religiosos, a Companhia de Jesus manifestava o espírito do tempo, que tinha a racionalidade mercante como uma de suas faces.

Em que pese a existência de outras fontes da Companhia de Jesus para o estudo da atuação jesuítica e da história da educação no quinhentos da América Portuguesa, elencaram-se as cartas enviadas do Brasil como as principais. Essasfontes foram constituídas a partir das Cartas Jesuíticas da edição da Edusp/Itatiaia e das cartas reunidas por Serafim Leite na série Monumenta Brasiliae. Ambas, abarcam as missivas enviadas pelos missionários atuantes na América Portuguesa no século XVI, mais precisamente entre os anos de 1549 e 1568. 
Para discutir o objetivo proposto, inicialmente será analisada a Companhia de Jesus dentro de seu contexto de fundação tanto europeu quanto lusitano, marcado por duas faces, a saber, o espírito reformista e a racionalidade mercantil. Em seguida, será abordada a atuação dos missionários no Brasil quinhentista, mormente no que diz respeito à conquista do índio à santa fé católica. Por fim, será apresentado o tema da dispensa das leis positivas presente nas cartas e discutido o seu alinhamento à racionalidade mercantil dentro do contexto do cumprimento da missão dos padres jesuítas em território tupiniquim.

\section{A Companhia de Jesus no contexto euro-lusitano: reformista e mercantil}

A Companhia de Jesus é fruto das contingências do século XVI europeu. Para os homens que viviam naquele momento, longe dos conceitos abstratos de pesquisadores que simplesmente a apontam como sendo a de um século em transição, a realidade lhes era palpável e concreta, reallidade). Não se davam ao luxo de passar a vida a refletir sobre as mudanças, mas sentiam o novo em sua pele. Consciente ou inconscientemente, agiam e reagiam consoante a realidade que se thes impunha. Foi nesses termos que nasceu a Companhia de Jesus. Inácio e seus companheiros, quando da fundação da nova Ordem, talvez jamais tivessem empreendido muito tempo a pensar acerca das contingências do momento em que viviam, mas criaram uma Ordem Religiosa com uma proposta totalmente voltada aos anseios dos homens inseridos naquela realidade.

século XVI europeu pode ser caracterizado como um período de efervescência de novos acontecimentos, de novos emparelhamentos religiosos, políticos, econômicos, sociais, demográficos, educacionais, culturais, valorativos, científicos, teóricos e materiais. Estava em curso uma série de mudanças que, aos poucos, transformaram a sociedade da Idade Média à Idade Moderna, de um modo de produção da vida feudal ao capitalista. A crise e a expectativa por uma reforma interna da lgreja, a formação dos estados nacionais, as grandes navegações, a descoberta de novos povos e territórios, o emergir do comércio, a incipiência e ascensão da burguesia, o pietismo novo, a Reforma Protestante, a Reforma Católica, a Renascença, o Humanismo, o 
Concílio de Trento, o desenvolvimento das ciências, dentre outros, são parte do que se denomina início dos tempos modernos.

Os contornos da Europa quinhentista vinham sendo delineados desde o renascimento comercial no Ocidente e se perfilavam com as descobertas marítimas. Diante dessas mudanças que se operavam, houve, entre outros, o emergir dos Estados Nacionais Absolutistas, a formação de uma nova classe social, a burguesia, e o desenvolvimento do Antigo Sistema Colonial. Gestante e gestada nesse processo foi a mentalidade da troca, do lucro e da riqueza monetária, a que foi denominada de racionalidade mercantil. Não obstante as peculiaridades dos Estados, que vivenciaram cada uma seu modo e consoante os próprios passos, essas mudanças se manifestaram em toda a Europa. Portugal, naturalmente, também esteve, pelas próprias conjunturas históricas, desde cedo, ligado a esse processo. Assim, o aspecto mercantil, que vinha sendo delineado, desde há muito, espraiava-se nas relações e nas vivências quinhentistas europeias, lusas e brasílicas. Nem todos os homens se tornaram mercadores, mas as vivências e as relações se tornaram interessadas.

Esse movimento social da modernidade também produziu as condições materiais e espirituais tanto para a Reforma Católica quanto para a Reforma 224 Protestante. Por causa do abuso de poder, dos benefícios exacerbados, da imoralidade, do enriquecimento, do envolvimento político, da superficialidade bíblica, das divergências de interpretação dos sacramentos, do ritualismo exterior e da escassez do culto interior, manifestados, muitas vezes, entre os padres e os membros do clero e da Cúria Romana, havia, desde os séculos anteriores, um espírito reformador, defendido por cristãos, clérigos e papas, que conclamavam mudanças de toda a ordem dentro da lgreja.

Em meio a esse contexto, houve uma renovação da piedade. Logo, "[...] o homem, mais do que nunca, continuava a crer" (SEBE, 1982, p. 13). Desse sentimento, surgiram, no século XVI, algumas ordens religiosas ${ }^{2}$ com o intuito de revigorar a lgreja, as quais apresentavam uma proposta completamente oposta à vida do clero e das ordens mais antigas e que vinha ao encontro dos anseios populares de então. A Companhia de Jesus, criada por Inácio de Loyola (1491-1558) e seus companheiros em 1534, como as outras ordens do século XVI, é fruto do movimento interno de reforma da lgreja e de restauração do Cristianismo e da renovação da piedade, institucionalizado em Trento. 
A nova Ordem Religiosa nasceu com o principal objetivo de empreender uma cruzada missionária à Palestina. Decidiram reconquistar Jerusalém, que estava na mão dos Mouros, mediante a pregação da santa fé católica. Esse foi o primeiro projeto dos jesuítas. Contudo, uma vez que o Mediterrâneo estava fechado e que, portanto, seria impossível embarcar para a Palestina, ficaram ao dispor do Vigário de Cristo, como já haviam decidido. De acordo com Ricardo Garcia-Villoslada (1991), Inácio, Fabro e Laínez chegaram a Roma, em 1537, e pediram audiência com Paulo III, colocando-se à sua disposição.

Desde que chegara a Roma, aconselhado por seus companheiros, Loyola, começou a elaborar a Fórmula, documento que deveria constar no pedido de oficialização da Ordem. Em cinco capítulos, Inácio traçou o caráter essencial da Companhia. Diante das denúncias que pesavam contra os jesuítas, foram levantadas fortes objeções dentro da Cúria Papal, quando do pedido de oficialização. No entanto, ante a comprovação de que eram inocentes das acusações e uma vez que havia pessoas influentes a seu favor, - Papa Paulo III, por meio da bula Regimini Militantis Ecclesiae, de vinte e sete de setembro de 1540, confirmou a Ordem criada por Inácio e seus seis companheiros.

Por exalarem um espírito reformista e missionário, os jesuítas foram convidados a ir para Portugal. D. João III, Rei lusitano, estava alinhado ao movimento reformista e pietista que rondava a Europa Católica. Naturalmente, Portugal também não se isentou da crise religiosa, que grassava tanto os membros quanto a liderança da lgreja. Dias (1960), historiador português, argumenta que

A crise dos costumes religiosos e das instituições religiosas afetou praticamente toda a Europa nos fins da ldade Média. Portugal, como era de prever, não escapou à regra. Não faltam indícios de onde se colige o estado sombrio, quer da vida cristã, quer do clero e das ordens monásticas, entre nós (DIAS, 1960, p. 33).

Quando da chegada dos jesuítas em seu território, em 1540, além desse espírito reformista português, havia outra face da realidade lusa, a saber, a mercantilista. Com o desenvolvimento do comércio, nos séculos XV e XVI, houve a necessidade de se buscar novas rotas comerciais, a fim de encontrar mercadorias que alimentassem as trocas comerciais. Iniciaram-se as grandes 
navegações. Povos se lançaram ao mar em busca de mercadorias que, ao serem comercializadas, enriquecessem seus reis e suas cortes. Nessa empreitada, da busca de produtos que, ao serem trocados gerassem lucros, o globo tomou novos contornos e, em última instância, a mercadoria arredondou o mundo (COSTA, 2004).

Portugal foi um dos pioneiros nesse mercado mundial. Na apologética assertiva do jesuíta português Serafim Leite, "[...] o mundo já se desvendou todo nos seus contornos geográficos, graças aos descobrimentos marítimos iniciados no século XV pelos portugueses, movimento em que o Mediterrâneo cedia o passo ao Atlântico e, com o Atlântico, a outros oceanos." (LElTE, 1993, p. 9). Nessa empreitada, o reino lusitano conquistou muitos territórios, contemplou o rápido aumento de sua nobreza e desfrutou de um crescimento em muitos setores. De acordo com José Hermano Saraiva,

A superioridade dos navios portugueses, o melhor emprego da artilharia e a agressividade de alguns grandes chefes militares permitiram o triunfo português. [...] A coroa portuguesa adquire assim uma nova dimensão. O pequeno Portugal ibérico transforma-se numa das maiores potências navais e comerciais da Europa (SARAIVA, 1996, p. 153).

Nessa perspectiva, um ponto a se considerar é que, em outros países da Europa, o início dos tempos modernos - sendo as grandes navegações e o alargamento da troca de mercadorias também parte desse novo momento - produziu a exaltação do homem e das nações, levando-os ao nacionalismo, como o germano-saxão, e ao grito de liberdade da lgreja Católica. Em Portugal, por outro lado, a pungência naval e mercantil o conduziram a uma aliança ainda mais forte com a Santa Sé (LEITE, 2000).

É evidente, portanto, que, se por um lado, Portugal esteve à frente de muitos países no que tange às grandes navegações, por outro, permaneceu ligado à soberania da lgreja. Ao mesmo tempo que se lançava a mares nunca d'antes navegados, exalava o espírito reformista interno da lgreja na primeira metade do século XVI e abraçou as resoluções tridentinas na segunda metade do referido século. Tudo sobre a concepção do orbischristianus. Portugal, inclusive, levou essa visão cristã do mundo para os territórios que conquistou. Sobre o orbischristianus, Paiva assim o explica: 
Célio Juvenal Costa | Anderson dos Santos de Oliveira

Céli Juvena Costa Anderson dos Santos de Oiveird

[...] é uma imagem cristã medieval do mundo. Fundou-se na crença de que o mundo é de Deus, cujo representante na terra é a lgreja Católica. Este Deus, por ser verdadeiro, exigia que todos o reconhecessem e the prestassem culto. A verdade absoluta, eis o princípio e o fim do 'orbischristianus.' Papa e reis tinham por missão precípua tirar-the os óbices, estender e sustentar a fé, fazer reinar a graça de Deus. [...] Não havia dualismo social: de um lado a sociedade civil e de outro a sociedade religiosa. Não! A fé informava a todos os gestos humanos, indicando em sua razão última, Deus, mas nem por isso tirava-thes o caráter de humanos: compreendia-o e respeitava-o. Destarte devia o rei governar, o comerciante tratar, o soldado conquistar, o navegante descobrir terras, o padre pregar ao rei, ao comerciante, ao soldado, ao navegante e abençoá-los, cada um continuando o seu ofício. Fosse qual fosse o ofício, todos eles se deixavam impregnar até a raiz pela fé, pela forma cristã de entender a realidade. Na base de tudo estava a crença firme de que o orbe era essencialmente cristão (PAIVA, 1978, p. 20-21).

O fato de ter se tornado uma potência no mercado mundial à época e aliado à lgreja Católica, Portugal obteve o direito do Padroado. Em razão dessa instituição jurídica, os monarcas portugueses detinham o poder espiritual sobre os seus súditos, tanto no reino como nas colônias. Eram responsáveis por toda a administração da religião, inclusive financeira, desde a arrecadação de fundos, o seu gerenciamento e o sustento de tudo o que envolvesse a religião. No que tange às missões, cabia ao Rei a edificação de igrejas, de casas e colégios, além do sustento de cada padre em particular. Era, em última instância, a união entre a empresa comercial/mercantil e a espiritual/religiosa. $O$ mesmo Rei que comandava a busca de mercadorias também era o responsável pela expansão do cristianismo nos lugares onde as extraia (COSTA, 2006).

A ida dos jesuítas para Portugal esteve diretamente ligada a esse espírito reformista e mercantil e ao direito do Padroado. Em Portugal, os padres reformados foram bem recebidos. A empatia foi tamanha que o Rei deixou de lado a ideia de enviá-los à Índia como missionários, causa pela qual os solicitara em seu reino. Aqueles padres conquistaram a confiança do Rei e da corte por se apresentarem comprometidos com um processo de reforma da lgreja, desejo este que também fazia parte dos projetos da Coroa. No entanto, os dois jesuítas haviam ido para Portugal com o claro intuito de serem enviados para missões além mar e, em razão disso, Inácio teve de negociar diretamente com o Rei, que permitiu a ida de Francisco Xavier para a Índia, mas reteve 
Simão Rodrigues consigo em Portugal. $\bigcirc$ fato é que os padres foram bem aceitos e acomodados em território luso. Foi o primeiro país que os solicitou para uma missão, onde estabeleceram a primeira Província da Companhia e tiveram a primeira casa, que se tornou a primeira instituição de formação.

Esse reformismo católico foi adotado, pela Coroa, não só no reino, mas em todos os lugares onde o Império chegou para dominar e mercar. Como já havia sérias críticas às demais ordens que exerciam tal função, nesse espírito reformador, D. João III decidiu chamar os padres renovados para exercer o Padroado em seus domínios. Costa assevera que "[...] junto com a espada do soldado ia a cruz do padre; junto com o poderio militar iam as levas dos soldados de Cristo; junto, enfim, com a cultura ocidental de corte ia a religião cristã." (COSTA, 2004, p. 107). E ainda,

A relação entre Portugal e a Companhia de Jesus era íntima no que se refere ao empreendimento comercial e colonial, uma vez que junto com a espada da coroa carregada pelos fidalgos, marinheiros e capitães portugueses ia a cruz da lgreja levada pelos padres, fundamentalmente, os jesuítas. Onde a Coroa chegou para comerciar, traficar, rapinar, dominar, colonizar, a Companhia chegou para pregar, converter, catequizar, organizar, aculturar. A espada e a cruz eram dois lados da mesma moeda na sociedade portuguesa do século XVI; o orbischristianus era a forma de ser religiosa e social, sendo que os jesuítas foram verdadeiros militantes dessa empresa tida como santa (COSTA, 2004, p. 19).

No exercício do Padroado Português, os jesuítas vieram para o Brasil, alinhados ao espírito reformista e mercantil. A decisão de D. João III de enviar os inacianos para cá foi tomada no contexto maior da oficialização do Brasil como Colônia. É em meio ao processo de afidalgamento da sociedade lusa, da crise de suas empreitadas no Ocidente e dos problemas enfrentados pela América Portuguesa que se insere a decisão da Coroa, tomada em 1548, de tornar o Brasil uma Colônia oficial (COSTA, 2004).

\section{A atuação educacional-catequética dos jesuítas no Brasil quinhentista}

No que diz respeito ao século XVI, e mais precisamente 1549-1600, os jesuítas enviados pelo Império Lusitano focaram sua missão em várias frentes 
que, em última instância, diziam respeito a dois objetivos: converter os índios ao cristianismo romano e transformá-los em súditos do Rei de Portugal. $\bigcirc$ espírito reformista os impelia a ir onde quer que o Papa os mandasse para levar um catolicismo reformado e conquistar as almas, como regia a Fórmula de oficialização da Companhia:

[...] se ligue cada um de nós com voto especial, de modo que, sem nenhuma tergiversação nem desculpa, nos tenhamos por obrigações a cumprir, sem delongas, e na medida de nossas fôrças, quando nos ordenar o actual Romano Pontícife e os que pelo tempo adiante the sucederem, para proveito das almas e propagação da fé, sejam quais forem as províncias a que nos enviar, quer nos mande para os turcos, quer para as terras de outros infiéis, ainda para as partes que chamam da Índia, como também para os países hereges ou cismáticos ou quaisquer nações de fiéis (LEITE, 2000, p. 9).

No caso da América Portuguesa, vinham exercer o Padroado em terra de infiéis, tanto com mandado do Papa, quanto do Rei de Portugal. Logo, além do cristianismo, era necessário, também, aportuguesar. A missão, com efeito, visava forjar, no índio, uma alma cristã-católico-portuguesa. Almas que, para os jesuítas, eram vistas como mercadorias religiosas. Não as mercadorias granjeadas para o aumento e sustento do poder temporal do Rei e do reino, mas para o aumento do poder espiritual do Rei e do Papa, na medida em que - no mercar das almas - tanto um como o outro viriam lograr êxito o empreendimento que tinham em comum, quer seja, a propagação e o crescimento do catolicismo reformado. Afinal, "a principal cousa" que moveu D. João III "[...] a mandar povoar as ditas terras do Brasil, foi para que a gente delas se convertesse à [...] Santa Fé Católica" (REGIMENTO DE TOME DE SOUZA, 1924 , p. 347).

Segue-se que a vinda dos jesuítas para o Brasil fazia parte de uma das mais destacadas funções dos padres renovados no império luso: as missões além-mar. E a principal atividade desenvolvida pelos missionários nas ditas terras do Brasil, tal qual em Portugal, foi a educação. No entanto, se lá a educação girava em torno do fortalecimento de uma cultura religiosa, aqui, mais do que isso, pois tinham de fazê-lo com os portugueses, também implicava incutir e forjar essa cultura nos autóctones. Conforme Leite, "[...] o fim principal da Missão do Brasil era a conversão do gentio, mas simultâneamente 
o de atender aos Portugueses, que tinham ido antes e chegavam de novo" (LEITE, 1956, p. 8).

Como pano de fundo de todo esse movimento, havia uma perspectiva de superioridade e veracidade cultural. Os jesuítas, assim como todos os seus contemporâneos portugueses, partiam do princípio de que a cultura ocidental europeia e portuguesa era superior à do índio e de que a religião cristã católica era a única verdadeira. $\bigcirc$ etnocentrismo português e o eurocentrismo não foram atitudes previamente racionalizadas e não eram exclusivas dos jesuítas. Pelo contrário, faziam parte do inconsciente coletivo de seus conterrâneos e contemporâneos. Todos os que aqui chegaram para colonizar o Brasil no quinhentos vieram com a mesma mentalidade. Não se trata aqui, pois, de defender ou de condenar os jesuítas, mas de afirmar que eles eram e agiam como homens do século XVI. Com efeito,

Cobrar daqueles padres comportamentos que a sociedade moderna demandou é, no mínimo, injusto para com eles, pois a mentalidade da época, que determinava suas concepções e projetos, era muito diferente da nossa, havendo uma razoável distância entre o que era vício e virtude para eles e o que o são para nós (COSTA, 2010, p. 199).

É fato, porém, que não houve, apenas, imposição, pois a adaptação também fazia parte da ação dos jesuítas. No Brasil, tanto se adaptaram quanto incutiram uma cultura, de modo que, de ambos os lados, houve um processo de aculturação, no sentido de agregação de mais uma cultura. Como a realidade da Colônia era totalmente distinta da europeia e portuguesa, os padres tiveram também de modificar algumas de suas práticas. Porém, entre os índios, esse processo foi bem mais intenso.

Assim que chegaram ao Brasil, os jesuítas partilharam da visão do índio como o bom selvagem, como uma espécie de tábula rasa em que poderiam "escrever" a religiosidade cristã, julgando, por conseguinte, que não constituiria tarefa muito difícil convertê-lo ao catolicismo e à cultura europeia portuguesa. Desse modo, adotaram medidas bem pacíficas. Contudo, o tempo tratou de thes mostrar que tal cousa era mais difícil do que julgaram a priori. Então, tiveram de adotar medidas mais severas, como o auxílio da armada nas viagens missionárias e o processo de aldeamento dos índios. Já que pela via pacífica os índios não cediam com tanta facilidade, os padres usavam o poder 
militar dos portugueses, que era bem superior ao dos aborígenes, para impor a fé e a cultura, ou seja, educá-los ${ }^{3}$.

Essa atuação dos jesuítas no Brasil do século XVI, de catequese e educação em meio aos índios, visando forjar um cristão católico reformado português, submisso ao Rei de Portugal e ao Papa, foi empreendida a partir de uma mentalidade mercantil, própria do contexto quinhentista lusitano. Assim como as mercadorias, o mercar das almas era quantificado e comemorado como o enriquecimento do reino espiritual.

Para desenvolverem a sua missão, os jesuítas encontraram dificuldades na terra dos brasis ${ }^{4}$, a saber: a) o estilo de vida pouco cristão dos colonos e comerciantes portugueses; b) os atrasos por parte dos responsáveis no pagamento dos dotes reais, que lhes era de direito devido ao exercício do Padroado; c) o relacionamento com os governos gerais, às vezes, avessos aos ideais da Companhia; d) o embate com aqueles imbuídos somente pelos interesses mercantis, que queriam escravizar os índios; el a vida imoral dos clérigos e os embates com os seus líderes entre outras. Muitas vezes, para se justificarem dos fracassos de sua empresa religiosa, os padres recorriam a esses problemas.

Devido, inclusive, a um desses problemas, as dificuldades enfrentadas com o primeiro bispo do Brasil, D. Fernandes Sardinha, avesso aos ideais de conversão dos gentios, é que a Missão Brasil foi erigida à Província da Companhia de Jesus. Somava-se a isso o rápido crescimento das missões no Brasil e as peculiaridades próprias da terra que praticamente impossibilitavam o Provincial de Portugal governá-la de tão longe. Assim, em nove de junho de 1553, Inácio de Loyola enviou uma carta a Nóbrega, então Superior da Missão Brasil, comunicando-lhe a elevação da Missão à Província e dando-lhe a patente de Provincial da Província do Brasil:

Inácio de Loyola, Prepósito Geral da Companhia de Jesus:

Ao dileto em Cristo Irmão P. Manuel da Nóbrega, presbítero da mesma Companhia, saúde sempiterna no Senhor.

1. Crescendo cada vez mais o número dos que em diversas regiões pela graça de N. S. Jesus Cristo seguem o nosso Instituto, cresce também a necessidade de prover a muitas coisas e portanto de dividir com outros este cargo; e pareceu no Senhor convir que, pondo em nosso lugar algum dos nossos Irmãos e constituindo-o Prepósito de todos os que vivem sob a obediência da nossa Companhia da 
Educação jesuítica na América Portuguesa: a dispensa das leis positivas e a racionalidade mercantil

Índia do Brasil, sujeita ao sereníssimo Rei de Portugal, e outras regiões mais além, ao mesmo confiássemos tudo o mais que pertence ao nosso ofício.

Nós, portanto, da vossa piedade e prudência, que está em Cristo Jesus, confiando muito no mesmo Jesus, vos criamos e constituímos, com toda a autoridade, que a Sé Apostólica nos concedeu e as Constituições da nossa Companhia nos conferem, e em virtude da santa obediência, Prepósito Provincial de todos os Nossos, que se encontram nas regiões indicadas; para que, tomando essa parte do nosso cuidado e autoridade, useis da mesma plenissimamente, para inquirir, ordenar, reformar, inibir, proibir, admitir na Companhia para a provação, e afastar da mesma os que vos parecer bem, prover em qualquer ofício e depor dele, e, numa palavra, para dispor de tudo, como se nós estivéssemos presente, poderíamos dispor, quanto a lugares, coisas e pessoas, e como julgardes convir para a glória de Deus. Contando com a graça de Deus, esperamos no Senhor que isto há de ser para a sua honra, proveito espiritual dos que dependem de nosso cuidado, a salvação das almas em geral. Dado em Roma, aos 9 de Julho de 1553 (LEITE, 1956, p. 508).

Além de apresentar em que constituía o encargo do Provincial, a carta 232 evidencia uma das peculiaridades da Província do Brasil: como os padres estão aqui exercendo o direito do Padroado Português e, portanto, sob as custódias do Rei, Manuel da Nóbrega tinha de continuar se remetendo a ele e aos companheiros lusos. Com efeito, os padres no Brasil, a despeito de já constituírem uma Província, continuavam subordinados tanto à Coroa quanto à Província de Portugal. Loyola sabia que, apesar das normas internas da Companhia, havia as relações de poder estabelecidas no Império Português e sempre lidou com tudo isso com muita perspicácia política. De acordo com Costa, "[...] a província portuguesa permaneceu como elo de ligação entre as províncias de além-mar e o generalato de Roma" (COSTA, 2006, p. 54).

Apesar de Inácio de Loyola, quando da eleição do primeiro Geral, ter dado o seu voto a Jesus ${ }^{6}$, a Companhia, a despeito de seus objetivos espirituais e religiosos, era uma instituição humana. Como tal, esteve sujeita às condições espaço-histórico-temporal. A Ordem nasceu sob os auspícios reformistas da Igreja e com o objetivo de reconquistar Jerusalém. Porém, com o tempo, assumiu tarefas afins que não estavam delineadas no seu primeiro esboço.

Foram a Portugal para se tornar missionários no Oriente. Além disso, ficaram no reino propagando e fortalecendo o catolicismo reformado por 
meio da educação, que acabou se tornando seu principal campo de atuação em todo o Império Português. Em território luso, pelo exercício do Padroado, aliaram-se ao projeto expansionista e, por consequência, também à lógica mercantil.

No que diz respeito ao século XVI, com ênfase no eixo Portugal-Brasil e mais especificamente no Brasil Colônia, é possível afirmar que toda a atuação da Companhia de Jesus esteve ligada diretamente às condições que as contingências da realidade europeia, portuguesa e colonial brasileira thes permitiv.

\section{A dispensa das leis positivas e a racionalidade mercantil}

As leis positivas não permitiam o casamento entre parentes, a saber, nos casos de consanguinidade. No entanto, os índios, na maioria dos casos, eram casados com os próprios familiares. Uma vez que não poderiam realizar os casamentos, os missionários ficavam impedidos de batizar os gentis. Logo, tais leis se tornavam um impedimento ao bom andamento das missões, que era dimensionado pela quantificação dos sacramentos. Diante disso, foram necessárias várias solicitações, feitas direta ou indiretamente à Cúria Romana, que culminaram na dispensa dessas leis para alguns casos específicos dos gentis.

Manuel da Nóbrega, em sua carta da Bahia de nove de agosto de 1549 ao P. Simão Rodrigues, pediu que o Provincial português intercedesse ao Papa para que "[...] as leis positivas não obriguem ainda este Gentio." (NÓBREGA, 1988, p. 83). Em outra carta, escrita em São Vicente, no último dia de agosto de 1553, ao P. Luís Gonçalves da Câmara, o Superior da Missão indicou que, no Brasil, havia "[...] impedimentos de afinidade e consanguinidade [...]" para os quais "[...] pelo menos até que do Papa haja geral indulto" (LEITE, 1956, p. 525). Em resposta a essa solicitação de Manuel da Nóbrega, o P. Juan de Polanco, por comissão do P. Inácio de Loyola, escreveu de Roma, no dia vinte e dois de fevereiro de 1554, ao P. Diego Miron, segundo Provincial português, comunicando que o Papa concedera a dispensa para o terceiro e quarto grau de consanguinidade, "[...] também temos conseguido a liberação, em terceiro ou quarto grau de consanguinidade e afinidade, por dez anos para os que se convertem ou para os novamente convertidos" (LEITE, 1957, p. 27). 
Educação jesuítica na América Portuguesa: a dispensa das leis positivas e a racionalidade mercantil

No mesmo ano, José de Anchieta escreveu de Piratininga, no dia primeiro de setembro ao Geral, P. Inácio de Loyola, expondo a dificuldade de batizar e casar os aborígenes, pois todos viviam em matrimônio com graus de parentesco. Diante disso, reclamou o afrouxamento das leis positivas, exceto em casos de consanguinidade de primeiro grau:

Ajunta-se a isso que, contraído o matrimônio com os mesmos parentes e primos, se torna dificílimo, se porventura queremos admiti-los ao batismo, achar mulher que, por causa do parentesco de sangue, possa ser tomada por esposa. $\bigcirc$ que não pequeno embaraço nos traz; porquanto, não podemos admitir a receber o batismo a que se conserva manceba. Por isso parece grandemente necessário que o direito positivo se afrouxe nestas paragens, de modo que, a não ser o parentesco de irmão com irmã, possam em todos os graus contrair casamento, o que é preciso que se faça em outras leis da Santa Madre Igreja, as quais, se os quisermos presentemente obrigar, é fora de dúvida que não quererão chegar-se ao culto da fé cristã; pois são de tal forma bárbaros e indômitos, que, parecem aproximar-se mais à natureza das feras do que à dos homens (ANCHIETA, 1988, p. 45-46).

Apesar da concessão das dispensas dos terceiros e quartos graus de consanguinidade, o P. Diego Mirón, em carta ao P. Inácio de Loyola, escrita em Lisboa, no dia dezessete de setembro de 1554, referiu-se ao indulto geral, ou às dispensações de todo o direito positivo, requeridas por Manuel da Nóbrega, uma vez que considerava mui necessárias para a realidade do Brasil:

As dispensações ou o indulto geral que pede o Pe. Nóbrega em sua carta acerta da consanguinidade e da afinidade, que naquela terra há que impedem o matrimônio, V.P. encomende-as ao Pe. Polanco que se despachem se já estão obtidas, porque, como V.P. verá na carta, diz que tem lá muita necessidade delas (LEITE, 1957, p. 126).

Em maio de 1556, Manuel da Nóbrega escreveu de São Vicente ao P. Inácio de Loyola solicitando um relaxamento do direito positivo além do que já havia sido concedido, ou seja, para os casos de segundo grau também, pois disso dependia o batismo dos gentis: 
Célio Juvenal Costa | Anderson dos Santos de Oliveira

Celio Juvena Costa |Anderson dos Santos de Oiveira

Gentio desta terra, como não tem matrimônio verdadeiro, com ânimo de perseverarem toda a vida, mas tomam uma mulher e apartam-se quando querem, de maravilha se achará em uma povoação, e nas que estão ao derredor perto, quem se possa casar, dos que se convertem legitimamente à nossa Fé, sem que haja impedimento de consanguinidade ou afinidade, ou de pública honestidade, e este nos é o maior estorvo que temos não os poder pôr em estado de graça, e por isso não the ousamos a dar o Sacramento do Batismo, pois é forçado a ficarem ainda servos do pecado. Será necessário haver de Sua Santidade nisto largueza destes direitos positivos, e, se parecer muito duro ser de todo o positivo, ao menos seja de toda afinidade e seja tio com sobrinha, que é segundo grau de consanguinidade, e é cá o seu verdadeiro casamento, a sobrinha, digo, da parte da irmã, porque a filha do irmão é entre eles como filha, e não se casam com as tais; e, posto que tenhamos poder de dispensar no parentesco de direito positivo com aqueles que, antes de se converterem, já eram casados, conforme as nossas bulas, e ao direito canônico, isto não pôde cá haver lugar; porque não se casam para sempre viverem juntos, como outros Infiéis, e se disto usamos alguma hora é fazendo-os primeiro casar, in lege natura, e depois se batizam (NÓBREGA, 1988, p. 148).

Também em 1556, o P. Luís da Grã escreveu de Piratininga ao mesmo destinatário e, ao abordar a realidade dos casamentos gentílicos entre parentes, intercedeu pela dispensa de todo o direito positivo tanto para os índios quanto para os mamelucos, "[...] e por isso bem vê V.P. quanta necessidade há do Padre Santo dispensar com estes índios tudo o que toca ao direito positivo, e o mesmo com os mamelucos" (LEITE, 1957, p. 295). No dia trinta de julho de 1559, Manuel da Nóbrega escreveu da Bahia ao segundo Geral, P. Diogo Laynes, e noticiou que, com as dispensas matrimoniais concedidas, a missão prosperava, [...] as graças impetradas já vieram em mui bom tempo e com elas havemos feito muita obra entre os novos convertidos, e dado remédio a muitas almas. $\bigcirc$ que mais houver para pedir, o tempo e a necessidade o mostrarão" (LEITE, 1558, p. 1 17).

De acordo com Manuel da Nóbrega, em outra carta ao Geral, escrita em São Vicente no dia doze de junho de 1561, os jesuítas tinham dúvidas sobre as dispensações, a saber, se ela abrangia também os mestiços, filhos de cristãos com índios: "[...] uma dúvida permanece, e é se as dispensações abrangem também os matrimônios contraídos com os filhos dos cristãos 
mestiços, porque alguns deles são tais que deles aos mesmos gentios há pouca diferença" (LEITE, 1958, p. 366).

batismo consistia no rito de iniciação dos gentios à vida cristã, ou o maior quantificador da prosperidade da missão, e o casamento era pré-requisito para tal sacramento. Assim, embora as fontes não permitam afirmar até quais graus e se também aos mestiços as leis positivas tenham sido dispensadas, é possível verificar que os jesuítas, para cumprir a missão, tiveram de recorrer ao relaxamento delas. Isso porque a realidade vivida entre os índios no Brasil era completamente diferente da realidade europeia e portuguesa.

Entende-se que o pedido de dispensa das leis positivas era motivado pela racionalidade mercantil. As solicitações pelo afrouxamento das leis matrimoniais, na verdade, não eram feitas a partir de uma questão doutrinal. Não era uma reformulação da teologia, mas a necessidade de prosperidade da missão. $\bigcirc$ batismo dos índios só poderia ser ministrado desde que eles cumprissem todos os requisitos legais estabelecidos pela lgreja. E o casamento dos aborígenes com os próprios parentes não era aceito pelos cânones eclesiásticos.

A doutrina, nesse caso, impedia a missão de colher os seus frutos. Assim, para a mentalidade jesuítica, plasmada também pela lógica mercantil, urgia ajustar a teologia. O importante, novamente, era manter o saldo positivo. José de Anchieta, por exemplo, em carta ao P. Inácio de Loyola, escrita de Piratininga, no dia primeiro de setembro de 1554, pediu o afrouxamento das leis positivas, em última instância, a fim de batizar os índios:

Contraído o matrimônio com os mesmos parentes e primos, se torna dificílimo, se porventura queremos admiti-los ao batismo, achar mulher que, por causa do parentesco de sangue, possa ser tomada por esposa. O que não pequeno embaraço nos traz; porquanto, não podemos admitir a receber o batismo a que se conserva manceba. Por isso parece grandemente necessário que o direito positivo se afrouxe nestas paragens, de modo que, a não ser o parentesco de irmão com irmã, possam em todos os graus contrair casamento, o que é preciso que se faça em outras leis da Santa Madre lgreja, as quais, se os quisermos presentemente obrigar, é fora de dúvida que não quererão chegar-se ao culto da fé cristã (ANCHIETA, 1988, p. 45-46, sem grifos no original). 
Célio Juvenal Costa | Anderson dos Santos de Oliveira

Em maio de 1556, Manuel da Nóbrega escreveu de São Vicente ao P. Inácio de Loyola apresentando a mesma razão:

Por isso não the ousamos a dar o Sacramento do Batismo, pois é forçado a ficarem ainda servos do pecado. Será necessário haver de Sua Santidade nisto largueza destes direitos positivos, e, se parecer muito duro ser de todo o positivo, ao menos seja de toda afinidade e seja tio com sobrinha, que é segundo grau de consanguinidade (NOBBREGA, 1988, p. 148, sem grifo no original).

A doutrina era um impeditivo à colheita. Caso ela se mantivesse intacta, a missão não lograria o êxito esperado e desejado. Dessa constatação, os padres foram levados a solicitar o relaxamento dela. Os jesuítas não estavam a analisar teologicamente a questão, se a doutrina seria ou não correta. Pelo contrário, estavam a agir norteados pelo interesse de auferir os emolumentos necessários ao empreendimento religioso. $\bigcirc$ espírito mercantil se impôs sobre o escolástico.

\section{Considerações finais}

A Companhia de Jesus emergiu do movimento interno de reforma da Igreja e esteve sempre antenada à lógica mercantil que - juntamente com a orbischristianus - esculpia as configurações daquela realidade. A vida cotidiana dos jesuítas, não obstante seus anseios e fins marcadamente religiosos, organizava-se a partir de uma racionalidade mercantil. Ao afirmar que agiam consoante uma lógica própria dos novos tempos que se apresentavam ante o renascimento comercial e as descobertas ultramarinas, não estamos defendendo em última instância que os padres reformados eram mercadores e nem que a religião tenha sido utilizada, de forma ideologicamente consciente, como subsidiária dos ideais mercantis.

Defende-se que o objetivo das missões jesuíticas no Brasil quinhentista era religioso e não mercantil. Se para os governantes e/ ou para os colonos que aqui viviam a religião acabou sendo utilizada como subsidiária dos interesses mercantis, para os jesuítas não. A leitura feita não permite afirmar $e$ nem negar tal cousa, mas possibilita concluir que os missionários do século XVI jamais usaram a religião em busca de fins comerciais. Os jesuítas agiam de acordo com a mentalidade mercantil, delineadora daquela realidade, a fim de 
angariar os fins religiosos. Religião e mercadoria eram dois lados da realidade una.

Os pedidos de dispensa das leis positivas são um dos pontos que revela que a atuação da Companhia de Jesus, com seus objetivos religiosos, pautava-se em uma racionalidade mercantil. A busca do sucesso da empresa religiosa, ou a necessidade do lucro, também direcionou as vivências dos missionários no Brasil quinhentista. A práxis daqueles mercadores de almas foi norteada pela lógica de se ver em vantagem. Assim, os missionários, em busca de resultados positivos, solicitaram a dispensa das leis positivas.

Os padres da Companhia de Jesus entendiam que a submissão pura e simples às regras positivadas em leis causava mais dificuldades do que facilidades à conversão, à catequese e à educação dos gentios aqui na América Portuguesa. Para que os lucros da empresa missionária se fizessem e compensassem todo o labor dispendido, era necessário atenuar o rigor de certas leis. $\bigcirc$ direito positivo continuaria a existir, pois era fundamental para a organização social, no entanto, para que não se perdessem novos cristãos e súditos do rei de Portugal era necessário que se afrouxasse um pouco os nós. Desta forma, os jesuítas, sabedores e defensores de estratégias próprias do agir missionário, conseguiriam alargar a religião cristã, acrescentando mais lucros ao seu empreendimento.

\section{Notas}

$1 \bigcirc$ autor Anderson dos Santos de Oliveira, doutorando do Programa de Pós-Graduação em Educação da Universidade Estadual de Maringá, infelizmente, veio a falecer entre o período de envio do artigo e o aceite. Como seu orientador e amigo, lamento muito o fato ocorrido, não só pelo pesquisador dedicado que era, mas, também, pela amizade que partilhávamos.

2 Costa (2004, p. 120), a partir da leitura de Daniel-Rops, apresenta algumas ordens que foram criadas neste período, como a dos Capuchinos, a dos Teatinos, a dos Barnabitas e a dos Somascos. Ao final, afirma que "[...] todas estas ordens precederam a fundação da Companhia de Jesus e, igualmente a ela, foram criadas no espírito reformador do período, denunciando, em geral, o estado tido como pouco cristão que as ordens religiosas tradicionais se encontravam."

3 Na definição de Pécora (1999, p. 395 e p. 399), a princípio os jesuítas usaram a "[...] via amorosa." Contudo, diante das resistências e das guerras dos índios, passaram a adotar "a via da experiência: a conversão pelo medo".

4 De acordo com Assunção (2000, p. 18), como havia várias castas de índios, os jesuítas "[...] quando se referiam ao coletivo utilizavam o substantivo brasis para designar aquelas tribos com as quais mantiveram contato regularmente." 
5 Tendo em vista que o português das cartas é arcaico, neste artigo fizemos uma atualização ortográfica e gramatical em todas as citações das mesmas, a fim de facilitar a leitura e de manter a fluidez textual.

6 A cédula de Inácio constava: "JESUS! Eu me excluo e cedo minha voz àquele que receber a maioria dos votos. Não designarei ninguém, mas se cada um o desejar, estou pronto a fazê-lo" (LACOUTURE, 1994, p. 106).

\section{Referências}

ANCHIETA, José de. Cartas - informações, fragmentos históricos e sermões. Belo Horizonte: Itatiaia; São Paulo: EDUSP, 1988. (Cartas Jesuíticas).

ASSUNÇÃO, Paulo de. A terra dos brasis: a natureza da América Portruguesa vista pelos primeiros jesuítas (1549-1596). São Paulo: Annablume, 2000.

COSTA, Célio Juvenal. A racionalidade jesuítica em tempos de arredondamento do mundo: o Império Português (1540-1599). 2004.246f. Tese (Doutorado em Educação) - Programa de Pós-Graduação em Educação, Universidade Metodista de Piracicaba, Piracicaba, 2004.

Fontes jesuíticas e a educação brasileira. In: COSTA, Célio Juvenal; MELO, Joaquim Pereira; FABIANO, Luiz Hermenegildo. Fontes e métodos em história da educação. Dourados: Editora UFGD, 2010.

Os jesuítas no Brasil: servos do papa e súditos do rei. Diálogos, Maringá, v. 10, p. 37-61, quadrimestral, 2006.

DIAS, José Sebastião da Silva. Corrente de sentimento religioso em Portugal (séculos XVI a XVIII). Coimbra: Universidade de Coimbra, 1960.

GARCIA-VILLOSLADA, Ricardo. Paris: amigos no Senhor. Os votos de Montmartre. In: GARCIA-VILLOSLADA, Ricardo. Santo Inácio de Loyola nova biografia. São Paulo: Loyola, 1991.

LACOUTURE, Jean. Os jesuítas - os conquistadores. Porto Alegre: L\&PM, 1994. (v. 1).

LEITE, Serafim. Breve história da Companhia de Jesus no Brasil 1549-1760. Braga: Portugal: Livraria A. I, 1993.

História da Companhia de Jesus no Brasil. Belo Horizonte/Rio de Janeiro: Itatiaia, 2000. (v. 1) 
(Org.). Monumenta Brasiliae. (1538-1553). Roma: A Patribus Eiusdem Societatis Edita. Monumenta Historica Societatis lesu; Monumenta Missionum Societatis lesu; Missiones Occidentales, 1956 (v. I, v. X, v. 79).

Monumenta Brasiliae. (1553-1558). Roma: A Patribus Eiusdem Societatis Edita. Monumenta Historica Societatis lesu. 1957 (v. II, v. 80).

Monumenta Brasiliae. (1558-1563). Roma: A Patribus Eiusdem Societatis Edita. Monumenta Historica Societatis lesu, 1858 (v. III, v. 81 ).

NÓBREGA, Manoel da. Cartas do Brasil. Belo Horizonte: Itatiaia; São Paulo: EDUSP, 1988. (Cartas Jesuíticas).

PAIVA, José Maria de. O papel da catequese dos índios no processo de colonização - 1549 1600. 1978. 128f. Dissertação (Mestrado em Educação) - Programa de Pós-Graduação em Educação, Universidade Estadual de Campinas, Campinas, 1978.

Religiosidade e cultura brasileira - séculos XVI e XVII. Maringá: EDUEM, 2012.

PÉCORA, Alcir. Cartas à Segunda Escolástica. In: NOVAES, Adauto (Org.). A outra margem do Ocidente. São Paulo: Companhia das Letras, 1999.

240 PORTUGAL. Regimento de Tomé de Souza. Litografia Nacional: Porto, 1924.

SARAIVA, José Hermano. História concisa de Portugal. Lisboa: Europa-América, 1996.

SEBE, José Carlos. Os jesuítas. São Paulo: Brasiliense, 1982.

Prof. Dr. Célio Juvenal Costa Universidade Estadual de Maringá Departamento de Fundamentos da Educação Programa de Pós-Graduação em Educação Grupo de Pesquisa Interinstitucional Educação, Cultura e História: Brasil, séculos XVI, XVII e XVIII | DEHSCUBRA Líder do Grupo de Pesquisa Laboratório de Estudos do Império Português | LEIP E-mail | celio_costa@terra.com.br 
Doutorando Anderson dos Santos de Oliveira

Programa de Pós-Graduação em Educação

Universidade Estadual de Maringá

Grupo de Pesquisa Laboratório de Estudos do Império Português | LEIP

E-mail | andersonsoliveira@yahoo.com.br

Recebido 12 maio 2015

Aceito 3 jun. 2015 